\title{
Perception of dimethyl sulfide (DMS) by loggerhead sea turtles: a possible mechanism for locating high-productivity oceanic regions for foraging
}

\author{
Courtney S. Endres* and Kenneth J. Lohmann \\ Department of Biology, University of North Carolina at Chapel Hill, CB\#3280, Coker Hall, Chapel Hill, NC 27599, USA \\ *Author for correspondence (endres@email.unc.edu)
}

\begin{abstract}
SUMMARY
During their long-distance migrations, sea turtles of several species feed on jellyfish and other invertebrates that are particularly abundant in ocean regions characterized by high productivity. An ability to distinguish productive oceanic regions from other areas, and to concentrate foraging activities in locations where prey density is highest, might therefore be adaptive. The volatile compound dimethyl sulfide (DMS) accumulates in the air above productive ocean areas such as upwelling and frontal zones. In principle, DMS might therefore serve as an indicator of high prey density for turtles. To determine whether turtles perceive DMS, juvenile loggerhead sea turtles (Caretta caretta) were placed into a water-filled arena in which DMS and other odorants could be introduced to the air above the water surface. Turtles exposed to air that had passed over a cup containing $10 \mathrm{nmoll}^{-1} \mathrm{DMS}^{\mathrm{Spent}}$ more time at the surface with their noses out of the water than control turtles, which were exposed to air that had passed over a cup containing distilled water. Odors that do not occur in the sea (cinnamon, jasmine and lemon) did not elicit increased surface time, implying that the response to DMS is unlikely to reflect a generalized response to any novel odor. The results demonstrate for the first time that sea turtles can detect DMS, an ability that might enable the identification of favorable foraging areas.
\end{abstract}

Key words: sea turtle, fronts, orientation, olfaction, migration, navigation.

Received 3 April 2012; Accepted 17 July 2012

\section{INTRODUCTION}

Numerous marine animals that migrate long distances, including fishes, sea turtles, seabirds and marine mammals, periodically forage in unfamiliar oceanic regions along their migratory route. Because all oceanic regions are not equally favorable in terms of foraging, an ability to rapidly identify favorable areas, and to concentrate foraging in such locations, might be adaptive.

The loggerhead sea turtle, Caretta caretta (Linnaeus 1758), undergoes one of the longest and most spectacular marine migrations. Young loggerheads leave their nesting beaches and embark on transoceanic migrations that last a period of years and span entire ocean basins (Carr, 1987; Bolten et al., 1998; Bowen et al., 1995; Lohmann et al., 2012). During these migrations, juvenile turtles spend considerable time foraging in the open sea, particularly near fronts and upwelling areas (Carr, 1986; Polovina et al., 2000; Polovina et al., 2001; Polovina et al., 2004; Cardona et al., 2005; Etnoyer et al., 2006). Adult marine turtles of several species have also been observed foraging near fronts and other productive locations (Luschi et al., 2003; Luschi et al., 2006; Lambardi et al., 2008; James et al., 2005; Eckert, 2006; Troëng et al., 2005).

Frontal areas, which typically occur in locations where water masses converge or diverge, are often characterized by high concentrations of phytoplankton (Belkin et al., 2009). When fed upon, phytoplankton release dimethylsulfoniopropionate (DMSP), which is cleaved to form the odiferous compound dimethyl sulfide (DMS) (Dacey and Wakeham, 1986). Because DMS volatilizes into the air (Andreae, 1990; Kettle et al., 1999), oceanic areas with an abundance of phytoplankton tend to have an increased concentration of DMS in the air above them (Andreae, 1990). DMS and its precursor DMSP also attract some zooplankton and small fish
(Steinke et al., 2006; DeBose et al., 2008), which in turn are eaten by other organisms. Thus, high concentrations of DMS in the open sea tend to be found in high-productivity areas with abundant prey that can be exploited by large, mobile predators.

Several such predators, including procellariiform seabirds (Nevitt et al., 1995), African penguins (Spheniscus demersus) (Cunningham et al., 2008; Wright et al., 2011) and harbor seals (Phoca vitulinis) (Kowalewsky et al., 2006), can detect DMS. At least some of these animals appear to use the presence of DMS to identify areas with abundant prey (reviewed by Nevitt, 2008). Given that sea turtles can detect airborne odors (Endres et al., 2009), it is plausible that they might also use DMS to locate favorable oceanic foraging areas.

We investigated whether loggerhead sea turtles are capable of detecting DMS by presenting captive turtles with this compound, as well as with several other odors, and observing their behavior. We report that concentrations of DMS comparable to those found in highproductivity oceanic regions elicited an increase in the amount of time that turtles spent at the surface with their noses out of the water; no such change in behavior was elicited by the scent of distilled water or by several other odorants that do not occur naturally in the ocean. These results demonstrate for the first time that loggerhead sea turtles can perceive DMS, giving credence to the possibility that turtles might use this volatile chemical as a foraging cue at sea.

\section{MATERIALS AND METHODS Animals}

The 11 loggerhead turtles used in the study were obtained as hatchlings from nests deposited on Atlantic Beach and Onslow Beach in North Carolina, USA. Turtles were taken initially to the North Carolina Aquarium at Pine Knoll Shores, where they were 
raised for 2 months before being transferred to the University of North Carolina at Chapel Hill. In Chapel Hill, each turtle was maintained in a separate tank in re-circulating artificial seawater (Crystal Sea, Baltimore, MD, USA) maintained at a temperature of 26 to $30^{\circ} \mathrm{C}$ under a $12 \mathrm{~h}: 12 \mathrm{~h}$ light:dark cycle. At the time of the experiment, turtles were between 11.3 and $12.6 \mathrm{~cm}$ straight carapace length and approximately 5 months of age. At both locations where the turtles were raised, they were fed Mazuri Omnivore Aquatic Gel-based diet (www.mazuri.com). During the time of the experiments, turtles were fed every day.

\section{Experimental setup}

Experiments were conducted at the University of North Carolina in a laboratory located near to where the turtles were housed. Trials took place in a fiberglass arena identical to those in which the turtles were kept. The arena measured $99 \times 53 \times 46 \mathrm{~cm}$. One of the short sides contained a clear Plexiglas window $(43 \times 36 \mathrm{~cm})$ (Fig. 1). During all experiments, the arena was filled with artificial seawater to a depth of $\sim 30 \mathrm{~cm}$. The salinity of the water was approximately $28 \%$. The top of the arena was open to the air.

Airborne odorants were delivered to the arena through a PVC pipe (length $=89 \mathrm{~cm}$, diameter $=5 \mathrm{~cm}$ ). One end of the pipe was angled down toward the surface of the water in the arena. The other was connected to a T-joint, which was arranged so that one opening was directed downward into a plastic cup while the other opening was located $2 \mathrm{~cm}$ from a small fan $13.3 \mathrm{~cm}$ in diameter (Fig. 1). The fan gently blew air into the pipe, over the cup containing the stimulus and into the arena. A video camera recorded turtles through the Plexiglas window at the front of the arena (Fig. 1). A curtain prevented turtles from seeing when an observer approached to present an odorant.

\section{Odorants}

Although the primary focus of our study was to determine whether turtles perceive DMS, an additional question was whether behavioral responses elicited by DMS are specific to this chemical or instead reflect generalized responses to any novel, airborne odor. For this reason we used five different odorant presentations: DMS at a naturally occurring concentration (Nevitt et al., 1995) and essential oils of lemon, jasmine and cinnamon (in two concentrations described below). The essential oils were chosen because they were likely to be completely novel; these odorants are not associated with food nor were turtles likely to have encountered them during their brief history in the wild before capture. Additionally, it is probable that the turtles could detect these odorants given that loggerheads have a large suite of functional olfactory receptor genes, suggesting that they have retained many of the olfactory capabilities of their terrestrial ancestors and can detect diverse odorants (Kishida et al., 2007).

The five odorants were prepared for the experimental apparatus as follows: (1) DMS: three to four drops of a solution of $10 \mathrm{nmoll}^{-1}$ DMS (Sigma-Aldrich, Milwaukee, WI, USA) mixed with $50 \mathrm{ml}$ distilled water $\left(\mathrm{dH}_{2} \mathrm{O}\right)$; (2) cinnamon: three to four drops of cinnamon essential oil (Now Foods, Bloomingdale, IL, USA) in

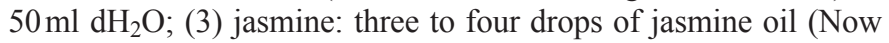

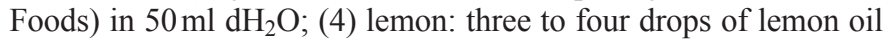

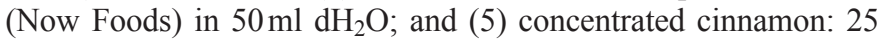

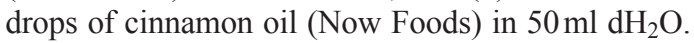

Because detailed information on the chemical composition of the essential oil samples was not available, it was not possible to calculate a molarity for these substances; however, all of these odorants were easily detectable by human observers at the concentrations used in the study. To reduce the likelihood that any failure of turtles to respond to the non-DMS odorants (see Results)

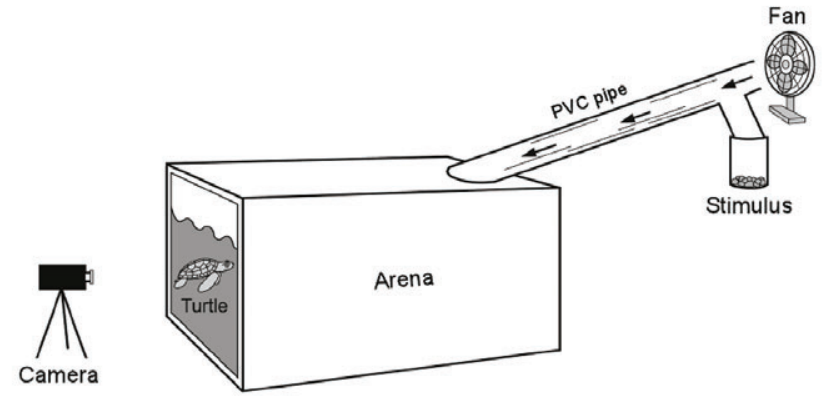

Fig. 1. Diagram of the experimental setup. Loggerhead sea turtles swam in a fiberglass arena with a window on one side, through which the behavior of the turtles was videotaped. Airborne odorants were delivered to the arena by a gentle stream of air. A small fan moved air into the PVC pipe, across the top of the stimulus cup, and into the arena

was due to the use of concentrations below the detection threshold, an elevated concentration of one of these odorants (25 drops of cinnamon oil) was also tested.

\section{Experimental protocol}

For each odorant, paired trials were used to monitor the behavioral response of each turtle to: (1) the odorant itself and (2) the odor of $\mathrm{dH}_{2} \mathrm{O}$ (as a control). To begin a trial, an empty plastic cup was affixed to the T-joint and the fan was turned on. A turtle was then placed into the arena and allowed to acclimate until it ceased making rapid movements (characteristic of escape behavior) and began to swim steadily, a process that usually took $\sim 10-20$ min (Endres et al., 2009). Occasionally, a turtle failed to swim and instead floated motionless at the surface of the arena for the entire acclimation period. When this happened, the turtle was excluded from trials for that day but was subsequently tested again the next day. Those few turtles that failed to swim on two consecutive days were eliminated from the experiment.

Once a turtle was swimming steadily, the recording equipment was turned on and the empty plastic cup was replaced with one containing either $\mathrm{dH}_{2} \mathrm{O}$ or the experimental odorant. A trial began after the turtle surfaced to take its first breath, which was presumably when it first had an opportunity to detect airborne odorants. The trial was videotaped for an additional 2 min after the first breath.

Upon completion of the trial, the stimulus cup was replaced with the empty cup and the fan was left on to allow lingering odorants to disperse. The door to the room was also left open to facilitate this dispersal. Once the room had been aired out for at least $10 \mathrm{~min}$, the door to the room was shut and the turtle was allowed to acclimate for another $10 \mathrm{~min}$ before it was presented with the second stimulus. Half of the turtles were exposed to the experimental odorant first; the other half were exposed to $\mathrm{dH}_{2} \mathrm{O}$ first.

Several days were usually required to subject all turtles to the same odorant. Once trials with each odorant had been completed, turtles remained undisturbed in their home aquaria for a minimum of 2 days before a new experiment involving a different odorant began. The sequence of odorants presented was DMS, cinnamon, jasmine, lemon and concentrated cinnamon.

\section{Data analysis and statistics}

The videotape of each trial was analyzed by two observers who had no knowledge of the purpose of the study or which stimulus had been presented to the turtles. Observers recorded the total number of seconds each turtle spent with its head above the surface of the water 


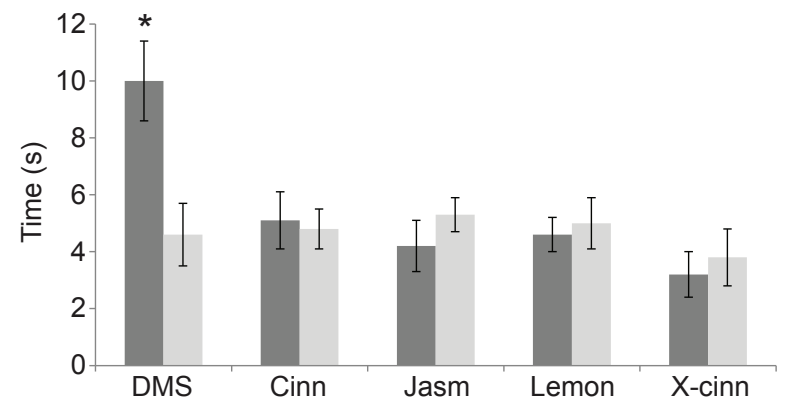

Fig. 2. Time (s) that loggerhead sea turtles spent with their noses out of the water in response to airborne odorants. Values indicate group means; error bars represent standard error. Dark gray bars represent results from trials involving the odorant indicated below each set of bars. Light gray bars indicate the corresponding control trials involving air scented with distilled water $\left(\mathrm{dH}_{2} \mathrm{O}\right)$. DMS, dimethyl sulfide; Cinn, cinnamon; Jasm, jasmine; X-cinn, concentrated cinnamon. Sample sizes were $N=11$ turtles for DMS trials and controls and $N=10$ for all other odors and controls. The asterisk denotes the only statistically significant pairwise comparison (see Results for details).

during each trial. Surface time was selected as a metric because preliminary observations suggested that turtles spend more time at the surface when odors associated with food are present. Although the reason for this behavior is not known, one possibility is that turtles sample the air more when they encounter olfactory stimuli that may be biologically meaningful.

The Wilcoxon signed-ranks test was used to compare responses of turtles to each odorant with responses to corresponding $\mathrm{dH}_{2} \mathrm{O}$ controls. The Kruskal-Wallis test was used to determine whether different responses were elicited by the five odorants tested (DMS, jasmine, lemon, cinnamon and concentrated cinnamon). The Mann-Whitney $U$-test was used to analyze differences between specific pairs of odorants.

\section{RESULTS}

Turtles spent more than twice as much time at the surface when DMS was present (mean $=10.0 \mathrm{~s}$ ) than they did during $\mathrm{dH}_{2} \mathrm{O}$ control trials (mean $=4.5 \mathrm{~s}$; Figs 2, 3). The difference in responses to these two treatments was significant (two-tailed Wilcoxon signed-ranks test, $t=10, P<0.05)$. By contrast, turtles did not show any difference in responses to any of the other odorants (cinnamon, jasmine, lemon or concentrated cinnamon) relative to $\mathrm{dH}_{2} \mathrm{O}$ controls (Wilcoxon tests, $P>0.1$ in all cases; Figs 2, 3).

The amount of time turtles spent at the surface in the presence of the five odorants tested was significantly different (Kruskal-Wallis test, $H=13.50, P<0.01$ ). Pairwise comparisons (Mann-Whitney $U$-test) indicated that time spent at the surface during DMS trials was significantly greater than surface time during cinnamon $(P<0.01)$, jasmine $(P<0.01)$, lemon $(P<0.01)$ and concentrated cinnamon trials $(P<0.001 ;$ Fig. 2$)$. These comparisons remain significant if the Bonferroni correction for multiple comparisons is applied (adjusted $\alpha=0.0125$ ), a practice recommended by some, but not all, statisticians (Perneger, 1998).

\section{DISCUSSION}

When DMS was present in the air, turtles spent significantly more time with their heads above water than they did when the air was scented with the odor of $\mathrm{dH}_{2} \mathrm{O}$. By contrast, air scented with cinnamon, jasmine, lemon or concentrated cinnamon failed to elicit more surface time than did corresponding $\mathrm{dH}_{2} \mathrm{O}$ controls. These data demonstrate that loggerhead turtles can perceive DMS.

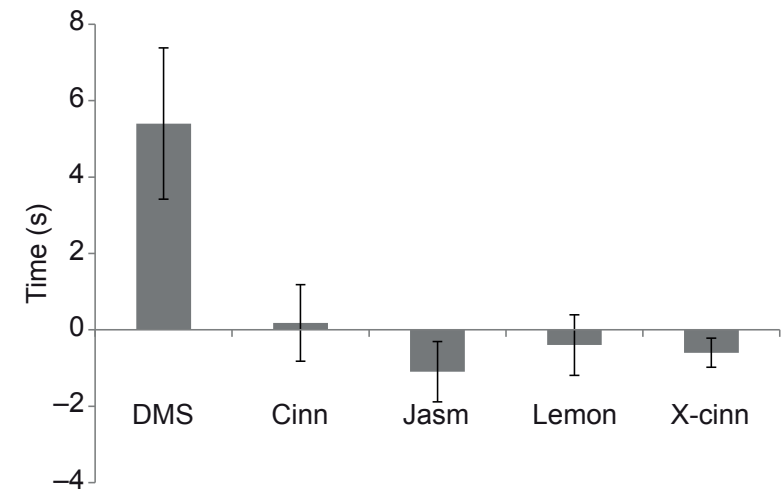

Fig. 3. Mean change in surface time elicited by each odorant. Bars for each odor indicate differences in surface time observed in experimental trials (in the presence of the odor) versus the corresponding $\mathrm{dH}_{2} \mathrm{O}$ controls. Error bars represent standard error. Conventions as in Fig. 2.

Why turtles responded to DMS by spending more time with their heads above water is not known. One possibility, however, is that airborne odors of biological importance, such as those associated with favorable foraging areas, attract the attention of turtles, leading them to linger at the surface while sampling the air more extensively than normal. This interpretation is consistent with preliminary observations suggesting that similar increases in surface time can be elicited in captive turtles by odors associated with their food (C.S.E., unpublished observations).

The failure of turtles to respond to cinnamon, jasmine and lemon odors implies that the response elicited by DMS is not a generalized response to all novel airborne odorants. One possibility is that turtles detected some or all of these odors but failed to respond to them behaviorally, just as the chicks of some seabird species perceive diverse olfactory cues but respond with searching behavior only when presented with odors associated with food (Cunningham et al., 2003; Cunningham et al., 2006). Alternatively, because cinnamon, jasmine and lemon are not odors that turtles are likely to encounter in the marine environment, turtles might not have evolved the olfactory receptors necessary to detect these odors, or they might have lost the appropriate receptors if they were once present in terrestrial ancestors.

In principle, the ability of turtles to detect DMS might allow them to use this odor to identify favorable oceanic foraging areas in much the same way that procellariiform seabirds do (Nevitt et al., 1995). For seabirds, experiments have demonstrated that birds approach ocean areas to which DMS had been added (Nevitt et al., 1995); foraging in areas with high concentrations of DMS is presumably advantageous because such areas are likely to be high-productivity locations with abundant prey (Nevitt, 2008). For similar reasons, turtles might forage preferentially in oceanic areas with high concentrations of DMS.

The behavior of loggerhead turtles in the north Pacific is consistent with this possibility. These turtles travel as juveniles from Japan and Australia to foraging grounds near Baja California (Bowen et al., 1995). To reach this area, turtles travel through the North Pacific Transition Zone, an area of convergent fronts and high productivity (Olson et al., 1994). Turtles frequently remain within these fronts, presumably to feed as they migrate (Polovina et al., 2000; Polovina et al., 2001; Polovina et al., 2004). Because these high-productivity areas are likely to have elevated concentrations 
of DMS, it is plausible that turtles might use DMS to help them remain in areas of high prey density.

Although our study was limited to loggerhead sea turtles, the close similarities in sensory abilities that exist among different species of marine turtles (e.g. Lohmann et al., 1990; Lohmann, 1991; Lohmann and Lohmann, 1993; Bartol and Musick, 2003; Southwood and Avens, 2010) suggest that other species might also have this ability. In principle, perception of DMS might be particularly useful for the leatherback turtle (Dermochelys coriacea), a species in which adults routinely forage in high-productivity areas such as frontal zones and upwelling areas (Luschi et al., 2003; Luschi et al., 2006; Benson et al., 2007; Saba et al., 2008; Lambardi et al., 2008). Such areas frequently have elevated levels of DMS (Andreae, 1990) as well as high concentrations of jellyfish, upon which leatherbacks feed. Leatherbacks are also commonly observed near shelf breaks (James et al., 2005; Eckert, 2006), another topographic feature associated with elevated DMS concentrations (Andreae, 1990). The possibility that leatherbacks exploit DMS as a foraging cue thus appears plausible.

Finally, because coastal waters often have elevated concentrations of DMS (Andreae, 1990), turtles might be able to use DMS to detect nearby islands under some circumstances. A role of airborne odorants in island-finding has been suggested (Luschi et al., 2001; Hays et al., 2003), although no unequivocal evidence for this presently exists (Lohmann et al., 2008).

The finding that sea turtles can detect DMS adds to the list of environmental cues they are known to perceive. Many questions remain, however, about whether and how turtles exploit this chemical in the natural environment. Further studies will be needed to examine whether turtles are attracted to DMS in the open ocean, and whether they can perceive other airborne chemical cues that may play a role in their long-distance migrations.

\section{ACKNOWLEDGEMENTS}

We thank Stacy Zhang and Julie Gassmann for analyzing videotapes. Catherine Lohmann, Dave Ernst and Roger Brothers provided helpful comments on manuscript drafts.

\section{FUNDING}

Funding for this research was provided by the National Science Foundation [grant IOS-1022005 to K.J.L.].

\section{REFERENCES}

Andreae, M. O. (1990). Ocean-atmosphere interactions in the global biogeochemical sulfur cycle. Mar. Chem. 30, 1-29.

Bartol, S. M. and Musick, J. A. (2003). Sensory biology of sea turtles. In The Biology of Sea Turtles, Vol. 1 (ed. P. L. Lutz, J. A. Musick and J. Wyneken), pp. 79-102. Boca Raton, FL: CRC Press.

Belkin, I. M., Cornillon, P. C. and Sherman, K. (2009). Fronts in large marine ecosystems. Prog. Oceanogr. 81, 223-236.

Benson, S. R., Forney, K. A., Harvey, J. T., Carretta, J. V. and Dutton, P. H. (2007). Abundance, distribution, and habitat of leatherback turtles (Dermochelys coriacea) off California, 1990-2003. Fish Bull. 105, 337-347.

Bolten, A. B., Bjorndal, K. A., Martins, H. R., Dellinger, T., Biscoito, M. J., Encalada, S. E. and Bowen, B. W. (1998). Transatlantic developmental migrations of loggerhead sea turtles demonstrated by mtDNA sequence analysis. Ecol. Appl. 8 $1-7$.

Bowen, B. W., Abreu-Grobois, F. A., Balazs, G. H., Kamezaki, N., Limpus, C. J. and Ferl, R. J. (1995). Trans-Pacific migrations of the loggerhead turtle (Caretta caretta) demonstrated with mitochondrial DNA markers. Proc. Natl. Acad. Sci. USA 92, 3731-3734.

Cardona, L., Revelles, M., Carreras, C., San Felix, M., Gazo, M. and Aguilar, A. (2005). Western Mediterranean immature loggerhead turtles: habitat use in spring and summer assessed through satellite tracking and aerial surveys. Mar. Biol. 147, 583-591.

Carr, A. (1986). Rips, FADS and little loggerheads. BioScience 36, 92-100.

Carr, A. (1987). New perspectives on the pelagic stage of sea turtle development. Conserv. Biol. 1, 103-121.

Cunningham, G. B., Van Buskirk, R. W., Bonadonna, F., Weimerskirch, H. and Nevitt, G. A. (2003). A comparison of the olfactory abilities of three species of procellariiform chicks. J. Exp. Biol. 206, 1615-1620.

Cunningham, G. B., Van Buskirk, R. W., Hodges, M. J., Weimerskirch, H. and Nevitt, G. A. (2006). Behavioural responses of blue petrel chicks (Halobaena caerulea) to food-related and novel odours in a simple wind tunnel. Antarct. Sci. 18, 345-352.

Cunningham, G. B., Strauss, V. and Ryan, P. G. (2008). African penguins

(Spheniscus demersus) can detect dimethyl sulphide, a prey-related odour. J. Exp. Biol. 211, 3123-3127.

Dacey, J. W. H. and Wakeham, S. G. (1986). Oceanic dimethylsulfide: production during zooplankton grazing on phytoplankton. Science 233, 1314-1316. PubMed

DeBose, J. L., Lema, S. C. and Nevitt, G. A. (2008). Dimethylsulfoniopropionate as a foraging cue for reef fishes. Science 319, 1356. PubMed

Eckert, S. A. (2006). High-use oceanic areas for Atlantic leatherback sea turtles (Dermochelys coriacea) as identified using satellite telemetered location and dive information. Mar. Biol. 149, 1257-1267.

Endres, C. S., Putman, N. F. and Lohmann, K. J. (2009). Perception of airborne odors by loggerhead sea turtles. J. Exp. Biol. 212, 3823-3827.

Etnoyer, P., Canny, D., Mate, B. R., Morgan, L. E., Ortega-Ortiz, J. G. and Nichols, W. J. (2006). Sea-surface temperature gradients across blue whale and sea turtle foraging trajectories off the Baja California Peninsula, Mexico. Deep Sea Res. Part II Top. Stud. Oceanogr. 53, 340-358.

Hays, G. C., Akesson, S., Broderick, A. C., Glen, F., Godley, B. J., Papi, F. and Luschi, P. (2003). Island-finding ability of marine turtles. Proc. Biol. Sci. 270 Suppl. 1, S5-S7.

James, M. C., Myers, R. A. and Ottensmeyer, C. A. (2005). Behaviour of leatherback sea turtles, Dermochelys coriacea, during the migratory cycle. Proc. Biol. Sci. 272, 1547-1555.

Kettle, A. J., Andreae, M. O., Amouroux, D., Andreae, T. W., Bates, T. S., Berresheim, H., Bingemer, H., Boniforti, R., Curran, M. A. J., DiTullio, F. R. et al. (1999). A global database of sea surface dimethylsulfide (DMS) measurements and a procedure to predict sea surface DMS as a function of latitude, longitude, and month. Global Biogeochem. Cycles 13, 399-444.

Kishida, T., Kubota, S., Shirayama, Y. and Fukami, H. (2007). The olfactory receptor gene repertoires in secondary-adapted marine vertebrates: evidence for reduction of the functional proportions in cetaceans. Biol. Lett. 3, 428-430.

Kowalewsky, S., Dambach, M., Mauck, B. and Dehnhardt, G. (2006). High olfactory sensitivity for dimethyl sulphide in harbour seals. Biol. Lett. 2, 106-109.

Lambardi, P., Lutjeharms, J. R. E., Mencacci, R., Hays, G. C. and Luschi, P. (2008). Influence of ocean currents on long-distance movement of leatherback sea turtles in the Southwest Indian Ocean. Mar. Ecol. Prog. Ser. 353, 289-301.

Lohmann, K. J. (1991). Magnetic orientation by hatchling loggerhead sea turtles (Caretta caretta). J. Exp. Biol. 155, 37-49.

Lohmann, K. J. and Lohmann, C. M. F. (1993). A light-independent magnetic compass in the leatherback sea turtle. Biol. Bull. 185, 149-151.

Lohmann, K. J., Salmon, M. and Wyneken, J. (1990). Functional autonomy of land and sea orientation systems in sea turtle hatchlings. Biol. Bull. 179, 214-218.

Lohmann, K. J., Luschi, P. and Hays, G. C. (2008). Goal navigation and islandfinding in sea turtles. J. Exp. Mar. Biol. Ecol. 356, 83-95.

Lohmann, K. J., Putman, N. F. and Lohmann, C. M. F. (2012). The magnetic map of hatchling loggerhead sea turtles. Curr. Opin. Neurobiol. 22, 336-342.

Luschi, P., Akesson, S., Broderick, A. C., Glen, F., Godley, B. J., Papi, F. and Hays, G. C. (2001). Testing the navigational abilities of ocean migrants: displacement experiments on green sea turtles (Chelonia mydas). Behav. Ecol. Sociobiol. 50, 528-534.

Luschi, P., Sale, A., Mencacci, R., Hughes, G. R., Lutjeharms, J. R. E. and Papi, F. (2003). Current transport of leatherback sea turtles (Dermochelys coriacea) in the ocean. Proc. Biol. Sci. 270 Suppl. 2, S129-S132.

Luschi, P., Lutjeharms, J. R. E., Lambardi, P., Mencacci, R., Hughes, G. R. and Hays, G. C. (2006). A review of migratory behaviour of sea turtles off southeastern Africa. S. Afr. J. Sci. 102, 51-58

Nevitt, G. A. (2008). Sensory ecology on the high seas: the odor world of the procellariiform seabirds. J. Exp. Biol. 211, 1706-1713.

Nevitt, G. A., Veit, R. R. and Kareiva, P. (1995). Dimethyl sulphide as a foraging cue for Antarctic procellariiform seabirds. Nature 376, 680-682.

Olson, D. B., Hitchcock, G. L., Mariano, A. J., Ashjian, C. J., Peng, G., Nero, R. W. and Podesta, G. P. (1994). Life on the edge: marine life and fronts. Oceanography 7, 71-82.

Perneger, T. V. (1998). What's wrong with Bonferroni adjustments. BMJ 316, 12361238.

Polovina, J. J., Kobayashi, D. R., Parker, D. M., Seki, M. P. and Balazs, G. H. (2000). Turtles on the edge: movement of loggerhead turtles (Caretta caretta) along oceanic fronts, spanning longline fishing grounds in the central North Pacific, 19971998. Fish. Oceanogr. 9, 71-82.

Polovina, J. J., Howell, E., Kobayashi, D. R. and Seki, M. P. (2001). The transition zone chlorophyll front, a dynamic global feature defining migration and forage habitat for marine resources. Prog. Oceanogr. 49, 469-483.

Polovina, J. J., Balazs, G. H., Howell, E. A., Parker, D. M., Seki, M. P. and Dutton, P. H. (2004). Forage and migration habitat of loggerhead (Caretta caretta) and olive ridley (Lepidochelys olivacea) sea turtles in the central North Pacific Ocean. Fish. Oceanogr. 13, 36-51.

Saba, V. S., Shillinger, G. L., Swithenbank, A. M., Block, B. A., Spotila, J. R., Musick, J. A. and Paladino, F. V. (2008). An oceanographic context for the foraging ecology of eastern Pacific leatherback turtles: consequences of ENSO. Deep Sea Res. Part I Oceanogr. Res. Pap. 55, 646-660.

Southwood, A. and Avens, L. (2010). Physiological, behavioral, and ecological aspects of migration in reptiles. J. Comp. Physiol. B 180, 1-23.

Steinke, M., Stefels, J. and Stamhuis, E. (2006). Dimethyl sulfide triggers search behavior in copepods. Limnol. Oceanogr. 51, 1925-1930.

Troëng, S., Evans, D. R., Harrison, E. and Lagueux, C. J. (2005). Migration of green sea turtles Chelonia mydas from Tortuguero, Costa Rica. Mar. Biol. 148, 435-447.

Wright, K. L. B., Pichegru, L. and Ryan, P. G. (2011). Penguins are attracted to dimethyl sulphide at sea. J. Exp. Biol. 214, 2509-2511. 